\title{
Nature-based solutions for urban landscapes under post-industrialization and globalization: Barcelona versus Shanghai
}

\author{
Peilei FAN ${ }^{* a}$, Zutao OUYANG ${ }^{\mathrm{b}}$, Corina BASNOU ${ }^{\mathrm{c}}$, Joan PINO ${ }^{\mathrm{d}}$, Hogeun PARK ${ }^{\mathrm{e}}$, Jiquan \\ $\mathrm{CHEN}^{\mathrm{f}}$
}

\footnotetext{
a School of Planning, Design, and Construction and Center for Global Change and Earth Observations, Michigan State University, East Lansing, MI 48824, USA; fanpeile@msu.edu
}

${ }^{\mathrm{b}}$ Center for Global Change and Earth Observations, Michigan State University, East Lansing, MI 48824, USA; yangzuta@msu.edu

c CREAF, Cerdanyola del Vallès, Spain; c.basnou@creaf.uab.cat

${ }^{\mathrm{d}}$ CREAF and Univ Autònoma Barcelona, Cerdanyola del Vallès, Spain; joan.pino@uab.cat

e School of Planning, Design, and Construction and Center for Global Change and Earth Observations, Michigan State University, East Lansing, MI 48824, USA; parkhoge@msu.edu

${ }^{\mathrm{f}}$ Department of Geography, Environment, and Spatial Sciences and Center for Global Change and Earth Observations, Michigan State University, East Lansing, MI 48824, USA; jqchen@msu.edu

${ }^{*}$ Corresponding author 


\begin{abstract}
Using Barcelona and Shanghai as case studies, we examined the nature-based solutions (NBS) in urban settings - specifically within cities experiencing post-industrialization and globalization. Our specific research questions are: (1) What are the spatiotemporal changes in urban built-up land and green space in Barcelona and Shanghai?(2) What are the relationships between economic development, exemplified by post-industrialization, globalization, and urban green space? Urban land use and green space change were evaluated using data derived from a variety of sources, including satellite images, landscape matrix indicators, and a land conversion matrix. The relationships between economic development, globalization, and environmental quality were analyzed through partial least squares structural equation modeling based on secondary statistical data. Both Barcelona and Shanghai have undergone rapid urbanization, with urban expansion in Barcelona beginning in the 1960s-1970s and in Shanghai in the last decade. While Barcelona's urban green space and green space per capita began declining between the 1950s and 1990s, they increased slightly over the past two decades. Shanghai, however, has consistently and significantly improved urban green space and green space per capita over the past six decades, especially since the economic reform in 1978. Economic development has a direct and significant influence on urban green space for both cities and post-industrialization had served as the main driving force for urban landscape change in Barcelona and Shanghai. Based on secondary statistical and qualitative data from on-site observations and interviews with local experts, we highlighted the institution'srole in NBS planning. Furthermore, aspiration to become a global or globalizing city motivated both cities to use NBS planning as a place-making tool to attract global investment, which is reflected in various governing policies and regulations. The cities' effort to achieve a higher status in the global city hierarchy may have contributed to the increase in total green space and urban green per capita. In addition, various institutional shifts, such as land property rights in a market economy vs. a transitional economy, may also have contributed to the differences in efficiency when expanding urban green space in Barcelona and Shanghai.
\end{abstract}

Key words:urbangreen planning, urbanization, green space, economic development 


\section{Funding sources:}

We would like to acknowledge the financial support from the National Aeronautics and Space Administration (NASA)'s Land Cover and Land Use Program through its grants to Michigan State University (NNX09AI32G and NNX15AD51G), the Asian Development Bank (ADB) through projects "Urbanization in Asia" and "The Urbanization-Poverty-Inequality Triangle in Asia and the Pacific”, and National Science Foundation of China (Project 71133004). 


\section{Introduction}

Nature-based solutions (NBS) is defined by European Commission as "living solutions inspired by, continuously supported by and using nature, which are designed to address various societal challenges in a resource-efficient and adaptable manner and to provide simultaneously economic, social, and environmental benefits” (European Commissions, 2015). Including actions in green space planning, waterfront redevelopment, neighborhood redevelopment and more, NBS has become a plausible concept to address the urban environmental challenges that arise as a city rapidly urbanizes. The concept is popular among planning professionals and decision makers in Europe (European Commission, 2015; Maes and Jacobs, 2015) and resonates in a number of theories relating to urban development, such as Kuznets Environment Curve (Stern et al, 1996), categories of environmental action taken by cities across different economic development levels (Satterthwaite, 1997), and the urban environmental transition theory (McGranahan et al, 2001). These theories distinguish one implication: NBS can only be pursued when a city reaches a certain economic development level.

Enthusiastic social reformers and planners within Western European and North American cities adopted the NBS framework during the industrial revolution (Le Gates, 2015). Exemplar redevelopment followed, including Regent Park in London by John Nash, Paris by Baron Haussmann, and the USA's Urban Park Movement led by Frederick Law Olmsted in the 19th century. Contemporary urban planning and design also emphasizes the importance of trees and large, aesthetic open spaces to city streets and walkways (Jacobs, 1995; Gehl, 2010), as well as its contributions to ecosystem functions and services, such as preserving biological diversity (Ahern, 2013) and improving air and water quality (Chen et al, 2016). In Europe, urban planners have continuously advocated that nature and climate factors, green views, and proximity and accessibility to green spaces should be integrated into sustainable urban planning (e.g., Gehl, 2010; Iojă et al, 2014). In Spain, for example, the Green Infrastructure and NBS concepts emerged as a new way to not only defend the value of ecosystems, but also mitigate climate and landscape change. With an objective to build "the green city of the future", Vitoria-Gasteiz promoted urban and peri-urban green spaces in northern Spain, which became the European Green Capital in 2012. The initiatives aimed not only to promote and develop green spaces in and around the city, but to also to enhance citizen participation during the development and implementation. In Barcelona, landscape design and gardening are developed with an understanding that "everybody should need 5 minutes walking till the nearest green area within the city" (Espuche et al, 2008). Similar NBS examples have been increasingly reported both in Europe and other regions (e.g., Artmann, 2014; Boone et al, 2009; Breuste et al, 2015; Chiesura, 2004; De Ridder et al, 2004; Kabisch et al, 2016; La Rosa, 2014; Niemelä, 2014; Rabinovitch and Reitman, 2004; Wolch et al, 2014). Not only are large cities in industrialized nations participating (e.g., New York, London, Tokyo, Paris, Barcelona), but also those in rapidly industrializing nations (e.g., Shanghai, Sao Paulo, Mumbai).

Unfortunately, there are limited empirical studies on how NBS are associated with postindustrialization and globalization, particularly from a comparative perspective (Fan P. et al, 2016; Gong et al, 2013; Tian et al, 2014; Zhou and Wang, 2011). There are a plethora of 
researches on various aspects related to NBS or on linkages between urbanization and economic development. For instance, the importance of green space planning for sustainable cities has been emphasized (Chen et al, 2015; Chiesura, 2014; Iojă, 2014, La Rosa, 2014; Maes and Jacobs, 2015). Green space planning has proven effective in improving urban environmental conditions, such as the urban heat island (Inostroza, 2014; Yue et al, 2012), air quality (Chen et al, 2015), and climate mitigation and adaption (Kabisch et al, 2016). As urbanization is driven by economic development, particularly post-industrialization and globalization, NBS policies and planning are needed as cities move up the ladder of economic development and citizens desire more urban amenities (Florida, 2005; McGranahan et al, 2001; Sassen, 1999; Satterthwaite, 1997). Nevertheless, there has been a lack of serious effort to link all these aspects together as an integrated analysis with drivers, patterns, and impacts centered around NBS and urban green planning. It is necessary to provide insightful views of inter-linkages between postindustrialization, globalization, and urban green space, and the impacts. This paper illustrates such an attempt and contributes to literature by both theoretical advancement and methodological contribution.

A critical question to start is: How did cities implement the NBS concept in their urban landscapes within the constraints of social and economic imperatives? To fill this knowledge gap, this paper presents a comparative case study on NBS for cities experiencing postindustrialization and globalization, using Barcelona and Shanghai as examples. Barcelona and Shanghai are treated as the potential front-runner and follower cities, respectively, to mirror the protocols of the Horizon 2020 program (European Commission, 2015). Barcelona is one of the world's leading green cities, which motivated our selection. Shanghai, a sister city of Barcelona, is labeled as a "follower city" to demonstrate the implementations of NBS-like concepts in other regions. The two represent industrialized vs. industrializing countries and market-based vs. transitional economies. As a region with a strong market-based economy, major metropolises in Western Europe led industrialization for most of the $20^{\text {th }}$ century and started postindustrialization in recent decades. London, Paris, Madrid, and Barcelona are the four largest metropolitan areas in Western Europe. However, Barcelona was selected because it is not a national capital. This allows the municipal government to have more control over urban land change, and thus, NBS analysis becomes more convenient. Shanghai is a good choice to compare with Barcelona because both cities have similar economic positions in their respective countries, including the economic structure resulting from a transitioned society (i.e., industrial to postindustrial), geographic and climate conditions, and impact from globalization. Both cities are located in relatively wealthy regions and have been the most important economic growth engines of their respective countries. They are also role models for other cities within their countries, demonstrating how to restructure from an industrial to a post-industrial economy and allowing the tertiary to become the dominant sector influencing economy. Geographically, they are both located in the coastal area of a sub-tropical climate. Both have integrated the global economy more successfully than the rest of their country, which is reflected byglobal trade volumes, global financial flows, as well as international tourists. More importantly, both municipal governments have committed to NBS in city planning and development, for which their invaluable lessons can be learnedby other cities with similar endeavors. Although others have conducted research on urbanization and green development in the case study city of Shanghai 
(Yue et al, 2012; Zhang, 2013; and Fan et al, 2017) and for Barcelona (Catalan et al, 2008; Llausas and Roe, 2012; and Basnou et al, 2013), their analyses are at different spatial and temporal scales, and thus difficult to compare. For example, Yue et al (2012) examined Shanghai's urban heat island in 2008 and how vegetation affected temperature and Fan et al (2017) evaluated the accessibility of its urban parks for 2000 and 2010. Zhang (2013) also reviewed the urban green development of Shanghai in the second half of the $20^{\text {th }}$ century, but spatial analysis was excluded. For the city of Barcelona, Catalan et al (2008),Llausas and Roe (2012), and Basnou et al (2013) studied urbanization, green infrastructure, and urbanization/forestation, respectively, but all had focused on certain time periods that did not extend to the most recent post-industrial decade. Catalan et al (2008) compared urban built-up land from 1993 to that of 2000 and focused on the transformations from an extreme compact to a polycentric urban form in Barcelona, but did not provide an analysis on urban green space.Llausas and Roe (2012) theorized and discussed the potential green infrastructure planning of the Catalonia region, in comparison with that ofnortheast England. Basnou et al (2013) generated land use land cover change maps for Barcelona from 1956 to 2000 and found that urbanization and forestation are the dominant pressures on biodiversity, followed by crop abandonment and deforestation. In this study, however, the temporal scale for NBS is extended as long as the data allowed, with spatial analysis spanning at least three decades. The spatial analysis for urbanization and green space was conducted at a reasonable spatial resolution(e.g., $30 \mathrm{~m}$ ofLandsat Thematic Mapper (Landsat TM) images).More importantly, previous research did not link green space development with the driving factors of economic development, particularly post-industrialization and globalization. By making these connectionsat the municipal scale through quantitative modeling, our research can bring significant insights to policy makers in Barcelona and Shanghai.

We aim at the following specific questions: (1) What are the spatiotemporal changes in urban built-up land and green space in Barcelona and Shanghai?(2) What are the relationships between economic development, exemplified by post-industrialization, globalization, and urban green space? To answer these questions, we first evaluate the spatiotemporal changes in urban landscapes within Barcelona and Shanghai from recent decades, with a focus on the green space. We then examine the relationship between economic development, globalization, and urban green space using structural equation modeling (SEM). We also highlight the underlying institutional and socioeconomic driving forces for the NBS through a review of NBS strategies and planning. Due to the insufficient data, our paper focuses on the spatiotemporal change of green space and its driving forces. Green space planning constitutes one of the most important elements of NBS and has been widely recognized as one criterion for an urban environment (Chiesura, 2004; Nature England, 2010). Following our previous work on urban green spaces (Fan et al, 2017), we define urban green spaces as public parks and other green spaces that are accessible to the general public and managed by the local government.

\section{Study area, data, and methods}

\subsection{Barcelona and Shanghai}

Located in the northeast coast of the Iberian Peninsula, Barcelona is the second largest city in Spain and serves as the economic trade center of the Mediterranean region (Fig. 1). Although the 
Gross Domestic Product (GDP) of Barcelona is much smaller than that of Shanghai, its GDP per capita (GDPpc) (\$50,800 in 2013) is much higher than that of Shanghai (\$14,700 in 2013) (Fig. 2). The municipality of Barcelona constitutes the core of the Metropolitan Area of Barcelona (MAB), with an area of $101.4 \mathrm{~km}^{2}$ and a population of 1.6 million in 2014. The MAB, including other municipalities, has $>3.2$ million inhabitants, making it one of the largest metropolitan areas in terms of population in Europe (http://ec.europa.eu/eurostat; last updated in 2016). Projections show that >5.1 million inhabitants will dwell in the MAB in 2050 (http://ec.europa.eu/eurostat). The MAB is also the core region of economic activity in the Catalonia Autonomous Region, owning $51 \%$ of the region's GDP. For the land use study, we include not only the municipality of Barcelona, but also the valley of the adjacent Llobregat River and part of the coastal mountain ranges in the MAB. The area is representative for the MAB, as it includes the city, its conurbation and the adjacent rural areas. Barcelona's NBS effort can be divided into three levels: municipal, metropolitan, and provincial levels. At the municipal level, the Barcelona City Council developed the Green and Biodiversity Plan (2012-2020) as its NBS strategy (http://ajuntament.barcelona.cat). Additional NBS strategies tackles the impacts of climate change, such as the $0.5^{\circ} \mathrm{C}$ temperature increase and the $40 \%$ decrease in rainfall expected by 2020 in the Mediterranean region. At the metropolitan level (www.amb.cat), the public administration responsible for territorial planning, urban planning and infrastructure development of the MAB has delineated the hot and cold spots of biodiversity, green areas and of ecosystem services and has established a framework to identify and mitigate future challenges under the NBS concept (Basnou et al, 2014). At the provincial level, the Barcelona Provincial Council has proposed various future strategies for NBS as well. Complex cartographic databases on biodiversity, green infrastructure and ecosystem services are available at landscape scale within the project SITXELL, the Territorial Information System for the Network of Open Areas in the Province of Barcelona (http://www.sitxell.eu/en/projecte.asp).

With a total population of 24 million in 2014 and an area of $6340.5 \mathrm{~km}^{2}$, Shanghai is the largest city in China (Fig. 1). With only $1.8 \%$ population of the nation, it harnessed $3.7 \%, 10.8 \%$, and $14 \%$, of China's GDP, trade, and foreign investment in 2014, respectively. This translates to a GDP of \$383 billion and a GDPpc of $\$ 15900$ (Fig. 2). The urban built-up area first appeared along the west bank of the Huangpu Rivers and has been expanding toward the Yangtze River in the north, with current development along the shorelines (Fan et al 2017). With a subtropical maritime monsoon climate, it has four distinct seasons. Shanghai's NBS effort for green infrastructure has focused on: (1) refurbishing old parks and creating new parks in the inner city by relocating some dilapidated neighborhoods and the manufacturing facilities; (2) creating large areas of forest parks outside the inner city, such as Shanghai Wild Zoo in Nanhui District (153 ha, 1995), the Century Park in Pudong District (140 ha, 2000), and five forest parks during 1985-2010; and (3) developing Chongming Island, a county of Shanghai and the third largest island in China, as a model ecological island that preserves natural resources and environmental quality for a circular and low carbon economy (Chen et al, 2008). For waterfront development, the city has focused on converting industrial land into parks, natural wetlands, and combined water areas for tourism and sport activities located mainly along the Suzhou River and Huangpu River. 


\subsection{Data and Analysis}

Using multiple data sources, we analyzed the NBS efforts and their consequences for Barcelona and Shanghai. Through Remote Sensing/Geographic Information Systems on satellite images, we derived spatial land cover and land use data, including green space and water features. We also used secondary statistical and qualitative data from in situ observations and interviews with local experts, etc. Based on these data, we first evaluated the urban land expansion and compared the speed and spatial configurations of urbanization for Barcelona (1950s-2010s) and Shanghai (1980s-2010s), with the aid of several landscape matrix indicators. We calculated a land conversion matrix to understand the major sources for creating urban green space. Urban built-up expansions were then compared with green space dynamics to reveal the association of green space to urban expansion. The complex relationship between economic development, globalization, and environment quality was further explored through the partial least squares structural equation modeling (PLS-SEM).

\section{Land cover and changes}

Urban built-up area was classified from Landsat TMimages for four periods (i.e., the 1980s, 1990s, 2000s, and 2010s) to examine spatiotemporal changes for both cities (Table 1). These images were downloaded from the United States Geological Survey (USGS) (https://www.usgs.gov/) Level-1 geo-referenced product, which were then converted to reflectance using the calibration function built-in ENVI 4.8. For each image, we classified it using ERDAS IMAGINE 9.3. First, we masked green vegetation using a normalized difference vegetation index (NDVI) (Rouse et al, 1974) threshold and masked the water surface with the modified normalized difference water index (MNDWI) threshold (Xu, 2007). The remaining image was then classified as urban built-up and non-urban built-up through supervised classifications. Post classification processes, including clumping, sieving, and combining classes were conducted to eliminate patches that were smaller than six TM pixels and to group all pixels into urban built-up and non-urban built-up area. Urban built-up area for Barcelona in 1956 was also extracted from the Land Cover Map of Catalonia (www.creaf.uab.cat/mcsc) at 5-m resolution. Without ground-truth references, it is difficult to accurately map the urban green land and water surface from historical Landsat images at 30-m resolution. To assure the data quality, we used higher resolution data to study spatial characteristics of urban green land and water surface areas. For Shanghai, we manually interpreted urban land, farmland, green land and water surface areas from the 5-m resolution Satellite Pour l'Observation de la Terre(SPOT) satellite images in 2000 and 2010. For Barcelona, we used the Land Cover Map of Catalonia in 1956, 1993 and 2009, which were generated by photo-interpretation on black/white (1956) or color ortho-photomaps (1993 and 2009) by the Cartographic Institute of Catalonia (Basnou et al, 2013). These land cover maps were originally in vector format with $20+$ classes. They were converted into raster format at 5-m resolution and reclassified into 4 classes (i.e., urban land, farm land, green land, and water surface) to match Shanghai data. To examine the spatial changes of green land and water surface areas, a selected subset of spatial metrics at both the class level (e.g., green land and water surface) and the landscape level were computed using FRGSTATS v4.2.1 (McGarigal et al, 2002) for 1993 and 2009 for Barcelona, and for 2000 and 2010 for Shanghai. 
Socioeconomic, population, and other statistical data and processing

To understand how NBS co-evolved with urban development, we collected data of demography, economic development, and environment in Barcelona and Shanghai, including population, immigrants, emigrants; GDP, GDPpc, percentages of primary, secondary, and tertiary industries of GDP, foreign direct investment (FDI), and foreign residents; as well as total urban green space (GREEN), and green space per capita (GREENpc). The major data sources are the Department of Statistics, Barcelona City Council (www.barcelona.cat),Instituto Nacional de Estadistica of Spain (http://www.ine.es), Statistical Institute of Catalonia (http://www.idescat.cat/en/), Shanghai Statistical Yearbook, and China Statistical Yearbook. We have some data available only for a larger geographic unit. For example, we only have the GDP of the Barcelona Province for some years rather than for the city. In these cases, we estimated the data either based on the previous year's proportion or on the average of the previous and the following year's proportion. In addition to government statistics, we also collected the master plans, documents of green space planning, relevant reports and news. We used the green space per capita data from statistical yearbooks rather than from our own spatial analysis because the PLS-SEM model needs yearly data that statistical yearbooks can provide, but our own analysis only generated green space data of three years. Furthermore, our own spatial data on green space mainly illustrates the spatial distribution for green space in connection with other spatial pattern of urban built up, and their numeric values of green space from our own spatial analysis are similar to those from the statistical books for these three years.

We interviewed local experts in urban development and green infrastructure planning in both Barcelona and Shanghai to help to identify the appropriated data sources and possible drivers for our study, and validate the result of our analysis. More importantly, they helped us to understand the dynamics of NBS-relevant policies in the past century in both cities. The interviewees provided us with the socioeconomic context, such as major driving forces of economic and the critical social events, to understand the background for NBS planning in both cities. Based on the interviews, we discussed the institutional role in NBS planning in Section 4.2, thus provide further insights to our readers on NBS planning and local context.

\section{PLS-SEM}

SEM is a statistical method to analyze multiple relationships among variables (Grace, 2006). It has been widely used in various disciplines due to the capacity of inclusion of both observable and unobservable variables that represent underlying relationships in the model (Fan Y. et al, 2016; Hair et al, 2011). In this study, we employed PLS-SEM to quantify the impact of economic development and globalization on urban environment (Figure 10). PLS-SEM is enabled to estimate complicated causal relationships with latent variables. It is a variance-based approach to minimize the error terms and maximize the explanatory power of the model (Hair et al, 2013). While PLS-SEM works efficiently with small and non-normally distributed data (Cassel et al, 1999), this technique cannot be applied to the circular relationships among latent variables. Consequently, we developed the unidirectional path to conduct the analysis. The PLSSEM model reflects the relationship between economic development, globalization, and GREENpc. 
Post-industrialization refers to the process where an industrialized economy transitions from the production of goods to the provision of services, marked with features such as the relative increase of importance of the service sector vis-à-vis the manufacturing sector and the increased valuation of information, knowledge, and creativity (Touraine, 1971; Bell, 1976). Globalization refers to the international integration process in various aspects, such as economic, cultural, and political (Amin and Thrift, 1994; Levitt, 1983; IMF, 2000a; Robertson, 1992; Sassen, 1999).

Economic globalization, i.e., the international integration of the world production system,mainly includes four aspects: global trade and product flows, global capital flows and foreign direct investment, global migration and people movement, and global information/knowledge flow/dissemination (IMF, 2000a).

Our underlying hypothesis is that economic development level can profoundly affect the urban environmental condition since NBS can only be pursued when a city reaches a certain economic development level (Satterthwaite, 1997; McGranahan et al, 2001). Further, in this increasingly globalizing world, a city's economic prospect is highly associated with its level of globalization (Sassens, 2001; Hall, 2002; Yusuf and Wu, 2002). Therefore, our PLS-SEM has the following structure: economic development and globalizations are two potential drivers for affecting urban environment, measured by urban GREENpc. Economic development was modeled as a latent variable based on the GDPpc and the proportions of the tertiary industry in GDP that measure the degree of post-industrialization. While GDPpc has been widely acknowledged as the indicator for level of economic development, post-industrialization (i.e., restructuring from manufacturing oriented to service oriented economy) is also considered highly associated with the level of a city's economic development (Florida, 2005). Globalization was another latent variable modeled by the trade variable (i.e., the proportion of export and import in GDP). For the environmental condition, we directly used an observed variable GREENpc, which was calculated based on population and the total urban green space (GREEN) from the city's statistical yearbooks (Barcelona City Council, 1996-2015; Shanghai Bureau of Statistics, 2000-2015). It is worth mentioning that in our interviews with the local experts, several of them mentioned how economic development, for instance, as reflected by post-industrialization and globalization, and particularly in Shanghai, have played an important role in green space planning.

Due to limited data for Barcelona, especially for economic data prior to the 1990's, we could not develop the model to include globalization for the city. We attempted to use different proxy variables (e.g., the number of foreign residents and tourists), but found that they poorly explained the relationship in the model. Thus, for the Barcelona model, we only developed the hypothetical latent variable of globalization and its paths along with other variables. The periods of the PLESEM analysis are 1986-2014 for Barcelona and 1978-2014 for Shanghai.

\section{Results}

3.1 Spatio-temporal changes of urban built-up area and green space

Barcelona expanded its urban built-up area rather steadily, with the main expansion occurring after the 1980s in the southwest and northwest along the Llobregat River Valley. The total urban built-up area in the 1950s, 1980s, 1990s, 2000s, and 2010s was 62.5, 131.6, 145.7, 188.4, and 
$233.3 \mathrm{~km}^{2}$, respectively. Shanghai has expanded its urban built-up area in all directions rapidly from the old city core, with its total urban area doubling each decade (Fig. 3). The total urban built-up area in the 1980s, 1990s, 2000s, and 2010s was 225.0, 553.5, 1599.5, and $2938.1 \mathrm{~km}^{2}$, respectively. The spatial distribution of green land in Barcelona did not change much from 1993 to 2009. In Shanghai, however, it changed significantly, with more green patches emerging in the urban core area (Fig. 4). In both cities, the patch density and the proportion of green land and water surface areas increased (Table 2). The average size of green land patches increased as well, but the average size of water surface decreased. The magnitude of the fraction of both green land and water surface did not change significantly in both cities. The diversity and evenness of the landscape decreased in Barcelona, but increased slightly in Shanghai.

\subsection{Association of urban green with urbanization and other urban landscape change}

GREEN and GREENpc remained relatively stable in Barcelona, whereas Shanghai increased these figures significantly since the early 1990s (Fig. 5). Barcelona's GREENpc started high at $18.03 \mathrm{~m}^{2}$ in 1956, but decreased to $13.16 \mathrm{~m}^{2}$ in $1977,11.43 \mathrm{~m}^{2}$ in 1993, and $6.2 \mathrm{~m}^{2}$ in 1998 . After 1998, it started to increase to $7.0 \mathrm{~m}^{2}$ in 2014. In contrast, Shanghai's average citizen only possessed $0.4 \mathrm{~m}^{2}$ of public green space at the beginning of economic reform in 1978, but this figure rose to $12.4 \mathrm{~m}^{2}$ in 2014- more than 30 times over the 36 years. While urban expansion reflected by urban population increase has a clear association of economic development, its relationship between urban population and GREENpc was not clear (Fig. 6). Urban population size appeared to be closely related to GREENpc in Shanghai, but not in Barcelona.

While urban built-up land experienced some expansion, GREEN and water surface area were kept almost the same, with farmland decreasing slightly from 1993 and 2009 (Table 3). Most conversion to urban land was from farmland and GREEN, whereas most GREEN was converted from farmland and urban built-up land in Barcelona. In Shanghai, urban built-up land and GREEN increased substantially at the expense of farmland and water surface area from 2000 to 2010. Most urban spaces were converted from farmland, water surface area, and GREEN during 2000-2010, whereas most GREEN was converted from farmland, followed by urban built-up land and water surface area.

3.3. Relationships among economic development, urban green space, and globalization Economic development in Barcelona positively affected the GREENpc (Fig. 7). A path coefficient of 0.528 implies that post-industrialization and economic growth promoted the GREENpc. While the model is statistically robust (i.e., variance inflation factor $>0.2$; average variance extracted $>0.5$ ), the $\mathrm{R}^{2}$ of the path between economic development and GREENpc is only 0.278 , suggesting the limitedness of our current model for Barcelona. For Shanghai, economic development has also strongly affected the GREENpc through a high path coefficient of 0.827 (Fig. 7). More specifically, post-industrialization (backed by the tertiary industry) and the level of economic development (i.e., GDPpc) have exerted great influence on the changes of GREENpc. The low value of the path coefficient $(<0.2)$ of the PLS-SEM model indicated that globalization did not directly affect GREENpc. However, globalization had an indirect effect on GREENpc through economic development, as evidenced by the positive influence of economic development (i.e., path coefficient of 0.729 ). The $\mathrm{R}^{2}$ between economic development and 
GREENpc are 0.667 and 0.532, respectively, between globalization and economic development, implying reasonable explanatory powers for the relationships. Moreover, high collinearity statistics of latent variables (variance inflation factor $>0.2$ ) and a high convergent validity (average variance extracted $>0.5$ ) indicate that our model for Shanghai is statistically robust.

\section{Discussion}

4.1 Urban green, post-industrialization, and globalization

Our findings on the influences of economic development on urban green spaces (Figs. 6 \&7) are consistent with previous studies that concluded that 'as economic growth increased municipal budgets and resources, local governments became more prone to preserve, restore, and create additional public green spaces to improve the urban environmental quality' (Chen and $\mathrm{Hu}, 2015$; Tian et al, 2014; Wolch et al, 2014). Here we emphasized that post-industrialization may play a significant role in light of the fact that substantial conversion from urban built-up land to green space has occurred for both cities. In Barcelona, while more than half of the agricultural land was lost to urbanization in the last 60 years, new forests resulted from agricultural land abandonment (Basnou et al, 2013; Parcerisas et al, 2012). Within the urban core of Barcelona, many vacant spaces or bare lands have converted into community gardens, which was encouraged by the City Council. For example, some parks on the seafront were created on old industrial lands. In Shanghai, in addition to the dominant conversion of agricultural land use to green space (Fan et al, 2017), most newly added public green space or redeveloped neighborhoods with refined green infrastructure (e.g., luxury green) had been converted from industrial lands and/or neighborhoods that were associated with industrial age when many residents were workers in manufacturing sectors.

Though the Barcelona model in our study is limited in explaining the impact of globalization on economy and GREENpc, there appeared indirect evidences demonstrating the results from other research. According to Metaxas (2010), Barcelona’s urban economy and FDI have grown simultaneously to a high level since the 1990s, indicating that a high level of globalization had been achieved for the city while it also improved its green space. For example, the flagship event of globalization for Barcelona, the Olympic Games in 1992, shifted strategic planning toward urban regeneration and public spaces (Monclús, 2003). The non-significant relationship between globalization and GREENpc in Shanghai may be due to the both positive and negative impact of globalization on urban green in the context of Chinese land management. The land-based development strategy in China involves the local government leasing land-use rights to private developers. While globalization may have positively affected economic development and thus lead to the increase of the urban green, the increasing financial and population flows due to globalization can also exert high demands on lands -- placing pressure on local governments to lease potential and existing green spaces in order to meet the global demand for land (Chen and Hu, 2015; Cho and Choi, 2014; Hsiao and Liu, 2004). It should be noted that the methodology (i.e., PLS-SEM)used to model the relationship between economic development and urban green space can also be used by other researchersfor analyzing the linkages between the driving forces and the outcomes of an NBS.

\subsection{Institutional role in NBS planning}


By reviewing the NBS strategies in Barcelona and Shanghai from the $20^{\text {th }}$ or $19^{\text {th }}$ century and our interviews with local experts, the cities' dynamic historical stages during urban development are revealed (Table 4).The planning effort at each stage appeared to synchronize with the mandate of socioeconomic development, thus indicating the important role of the institutions in NBS planning. As industrialization began in the $19^{\text {th }}$ century, Barcelona expanded its medieval city core. A visionary urban planner, Ildefons Cerdà designed the Eixample District (1850s), which is famous for its grid street layout and Catalan modernist architecture. The district remains the best reflection of Barcelona's unique urban landscape. However, the first space specifically designed to be a public urban green space in Barcelona during the $19^{\text {th }}$ century was the Parc de la Ciutadella (31 ha). It was not until the World Expo in 1929 that additional urban green space was added with the creation of Montjuïc Park at Montjuïc Mountain (203 ha) -- one the largest green areas in Barcelona. The three-year Spanish Civil War that started in 1936 had a profound negative effect on the economic development of Barcelona. Nevertheless, due to the strong industrial base and accumulated prosperity of the Cataluña region, Barcelona experienced an urban boom from the 1950s till the 1980s. Particularly in the 1960s, it received a large inflow of migrants from other poor regions of the country due to the agrarian crises. Barcelona witnessed the revival of the tertiary sector and a stabilized population in the 1980s, but a decreased rate in urban expansion. The continuous urban growth led to the expansion of the urban built-up area and a subsequent decrease in total urban green space and GREENpc. The municipal government started to take this issue seriously and created new green areas (e.g., the Metropolitan Park of Collserola, the green belt of the city of 8000 ha under a special protection plan in 1987). The Olympic Games in 1992 marked an important milestone for urban regeneration and tourism revival for the city. Since 1992, the city’s NBS effort has been characterized by the ecologically restored seafront and the many new parks covering old industrial land. Currently, NBS effort focuses on promoting and increasing green space and biodiversity at various levels (city and metropolitan area), including green corridors, urban gardens, living roofs, gardens on vacant spaces, etc. At the metropolitan scale, the Besòs and Llobregat Rivers had been ecologically restored in the 2010s. However, the economic crises in Europe in 2008 seriously affected the economy of Spain, with the unemployment rate significantly increasing in 2010 and residential poverty rates increasing to 20\% in 2011 across the MAB (www.amb.cat). These changes may have negatively impacted NBS implementations. The city, however, has started to show a recovering economic trend in recent years (www.ine.es). Barcelona's shift towards decentralized urban governance is resulting in an increased public engagement (Marshall, 2000), which may in turn affect the increase of public green spaces.

Shanghai had no NBS-like planning at the municipality level prior to 1949, with GREENpc at $0.13 \mathrm{~m}^{2}$. During the socialist central planning period (1949-1978), building an industrialized and production-oriented city was a higher priority than the residents' wellbeing. This slowed the pace of green space development in form of parks. NBS-like planning focused on converting some of the dilapidated areas within the city core into urban parks (e.g., Yangpu Park, Changfeng Park, and Xijiao Park in Yangpu District, Putuo District, and Changning District) and renovating the Bund Riverside Green Boulevard and Zhaojiabang Green Boulevard. Over the 30 years, urban public green space per capita reached $0.47 \mathrm{~m}^{2}$ in 1978. Since then, the economic reform has been driving rapid urban expansion in Shanghai, with NBS-like planning combining with urban 
development efforts, as reflected in the master plans of Shanghai for green space planning in 1986 and 1996. During 1978-1998, the city focused on developing a green belt on the outer ring road and creating a green space network featured by the points, lines, and areas of green spaces. As a result, several large green spaces were built along the outer ring road. After 1998, green space planning took off as Shanghai planned its development strategy to place the tertiary sector as the priority over the secondary sector. After approval of the 1999-2020 Master Plan by the central government, Shanghai changed from the piecemeal approach of "inserting greenness in city" to "green space planning”, proposing comprehensive networks of green belts, wedges, corridors, parks, and forests. During this period, urban public green space per capita jumped from $3.0 \mathrm{~m}^{2}$ in 1998 to $8.8 \mathrm{~m}^{2}$ in 2005, passing that of Barcelona and many other cities in the developed countries. From 2005 to 2009, the city’s urban green space planning has been tremendously affected as Shanghai fully embraced the opportunity of globalization. Ambition to rebuild the city as an international financial center and shipping hub in East Asia arrived with the opportunity to host the World Expo. NBS focused on building a high-quality environment to attract global investment and elite professionals. It proposed spatial configurations connecting green nucleus, belts, corridors, wedges, and networks. Prior to the World Expo opened in Shanghai, the city converted prime locations along the Huangpu River in the city center from manufacturing lands into green spaces, wetlands, and waterfronts along with other types of systematic green infrastructure, including national forest parks in the outer suburbs. Since 2009, as a regional center for global economics, finance, trade, and shipping, Shanghai has kept this momentum of promoting green space. At this stage, the concept of an "ecological city" was proposed to encourage urban sustainability and to institutionally streamline planning and land management. As a result, the Bureau of Urban Planning and the Bureau of Land Management merged for efficiency.

\subsection{Barcelona and Shanghai in comparison}

Shanghai has had a significantly higher rate in recent decades when comparing increasing GREEN and GREENpc to Barcelona. This implies that Shanghai was more proactive than Barcelona to implement NBS strategies in recent decades. The difference may be attributed to different timing in achieving a certain level of global city status and the different institutions and economies. Since the seminal work of Hall (1966), there have been numerous attempts to define the hierarchy of the global city, or the world city systems, by location preferences of multinational corporations' headquarters (Hall, 1966; Hymer, 1972), by ranks as major financial center (Reed, 1981), and by engagement with the internationalization, concentration, and intensity of producer service (Sassen, 1991). It is widely acknowledged that New York, London, and Tokyo are at the top level of global cities, but there exist divergent views on the second or third tier cities in the hierarchy due to the different criteria used in evaluation. Beaverstock et al (1999) categorized world cities based on four sub-sectors of corporate service provision: accountancy, advertising, banking, and legal services. Their roster shows 10 Alpha, 24 Beta, and 15 Gamma world cities, with Barcelona and Shanghai falling into the Gamma world cities category. While Barcelona has enjoyed a well-established reputation as a global city for several centuries because of its rich economic, cultural, historic, and natural assets, Shanghai only joined the global urban hierarchy in the past three decades -- despite facing intense competition from other global cities in the region (e.g., Tokyo, Seoul, Hong Kong, and Singapore). The city is 
much more eager than Barcelona to boost its urban image by improving its urban environment to match its rising economic power and new status as a globalizing city (Beaverstock et al, 1999; Yusuf and Yu, 2002). Strong municipal financing for Shanghai's NBS effort resulted from the rapid economic growth of the city.

Another consideration when comparing the two cities is their institutional context, such as different land property rights in a market economy vs. in a transitional economy. A transitional economy is defined as an economy changing from a centrally planned economy to a free market (Feige, 1994). Since the late 1970s, numerous countries in Asia and Eastern Europe have started transitioning processes, characterized by liberalization, macroeconomic stabilization, restructuring and privatization, and legal and institutional reforms; albeit at different times and various degrees of implementation (IMF, 2000b; Ianchovichina, 2007; Kubo, 2013). China has become a transitional economy since its reform in 1979 and has been on the road for high economic growth ever since. Institutional contexts have played a key role in differentiating the efficiency of expanding urban green spaces in Barcelona and Shanghai. In most market economies (e.g., Spain), lands are privately owned, suggesting that the municipal governments have relatively limited power to acquire and convert private lands. In transitional economies (e.g., China), all lands are essentially publicly owned, but can be leased to different individuals or organizations. It is no surprise that the municipal government of Shanghai may have more leverage than that of Barcelona in controlling land use (e.g., urban green land). Regardless, ownership held by multiple public organizations may result in a conflicting interest in land use and land use decisions. One caveat is that our data on GREENpc for Shanghai may be overestimated. Due to data limitation, we used the official household registered population (e.g., 14 million in 2014) to calculate GREENpc rather than its residential population (e.g., 24 million in 2014), which was almost $70 \%$ more than its registered population. This significantly elevated its value.

\subsection{NBS, social equity, and limitations of the study}

There are, however, several limitations of our studies. First, we did not study the connections to social equity, as both cities expanded their urban green space. This leads to two major uncertainties: (1) while both Barcelona and Shanghai had increased urban green space over time, it is uncertain if all residents of both cities have equally benefited from the outcome; and (2) at the local scale, NBS and the increasing green spaces usually do not equally benefit all residents. When an NBS is implemented, high or middle-income residents gain easier access to natural assets, while low-income or marginalized communities are relocated when their neighborhoods are converted or simply lacking access to the green spaces (Fan et al, 2017; Chen and Hu, 2015). Thus, green gentrification or green luxury spatial manifests at the local level. Some scholars thus suggested that planning to be "just green enough", such as using green spaces at schools or converting polluted areas into urban green, can address social equity and avoid the trap of NBS (Curran and Hamilton, 2012; Iojă et al, 2014; Wolch et al, 2014). Our recent study on public urban green area accessibility in Shanghai (Fan et al, 2017) reveals that the urban periphery fell behind the city average, regardless of improved accessibility to urban green spaces from 2000 to 2010 for all districts. We speculate that Barcelona could go either way. Under a strong public hearing and a NBS to distribute greenery more evenly across its landscape, Barcelona created 
many small green spaces throughout the city in high and low densities (Catalan et al, 2008; Llausas and Roe, 2012). This may contribute to resident accessibility. Due to unavailable data on Barcelona, we could not compare the accessibility of public urban green spaces in Barcelona and Shanghai.

Second, we did not consider social equity beyond the boundary of the respective cities. Critics noted that the NBS is centrally located. Quite often, decision makers protect their local environmental interest and ignore the external impact of their decisions, violating the geographical equity -- a key principle to sustainable development (Beatley, 1991; Haughton, 1999). For example, cities in developed countries get greener as they relocate manufacturing plants to developing countries. Under this context, the impact of post-industrialization of Barcelona and Shanghai shall be also measured for other affected places. Future research should incorporate the measurement of both the distant effects and external impacts of the local decisions on NBS.

Finally, our study is imperfect because of the data and methods. While our PLS-SEM model covers the most important and dramatic period of urban transformation and economic development in Shanghai's restructuring, it does not include the 1960s and 1970s for Barcelona, thus limiting our study. Another limitation lies in the shortcoming of the PLS-SEM itself, as it cannot be applied to the circular relationships among latent variables. Our underlying assumption of the uni-directional between economic development and green space may be challenged because some argue that urban green space, as a part of urban amenity, can help attract knowledge-based professionals, further stimulating economic development in the city (Florida, 2005). Thus, economic development and urban green space may constitute a circular relationship. Similar issues may exist for the uni-direction of globalization and urban green space in the PLS-SEM model. However, we draw a conclusion with the uni-directional path model of the PLS-SEM due to limited sample sizes. Other models (e.g., Covariance Based SEM equipped with bi-directional paths) with large samples that can address the circular relationships between latent variables shall be explored when more data are collected. Moreover, it was difficult to provide solid evidence in terms of the efficacy of planning policies and major events (e.g., the Olympic Games in Barcelona and the World Expo in Shanghai) in NBS implementation due to the difficulty to quantify the policies into quantitative values PLS-SEM incorporation at this stage. This is an important aspect for NBS studies, which should be addressed in future research.

\section{Conclusions}

Using Barcelona and Shanghai as case studies, we examinedthe NBS from urban settings in cities experiencing post-industrialization and globalization. Both Barcelona and Shanghai had undergone rapid urbanization, with urban expansion in Barcelona beginning in the 1960s-1970s and Shanghai in the most recent decade. Urban green space and green space per capita for Barcelona first declined from the 1950s to 1990s, and then slightly increased in the past two decades. However, Shanghai had a significant improvement in both values in the past several decades. Economic development has a direct and significant influence on urban green space for both cities. The values of path coefficients in the PLS-SEM model between economic development and green space per capita, and between economic development and percentage of 
the tertiary sector, both complimented the significant conversion from urban built-up land to urban green land. This indicates that post-industrialization had served as the main driving force for urban landscape change in Barcelona and Shanghai. Aspiration to become a global or globalizing city for Barcelona and Shanghai has motivated both cities to use NBS planning as a place-making tool to strengthen city image and attract global investment. This is reflected by various governmental policies and regulations over the years and global events, such as the 1992 Olympic Games in Barcelona and the 2010 World Expo in Shanghai. The cities' effort to achieve a higher status in the global city hierarchy may have contributed to their speed and level of increase in total green space and urban green per capita. In addition, the different institutional contexts, such as land property rights in a market economy vs. a transitional economy, may also contribute to the differences in efficiency when expanding urban green space in Barcelona and Shanghai.

\section{Acknowledgements}

We would like to acknowledge the financial support from the National Aeronautics and Space Administration (NASA)'s Land Cover and Land Use Program through its grants to Michigan State University (NNX09AI32G and NNX15AD51G) and the Asian Development Bank (ADB) through projects "Urbanization in Asia" and "The Urbanization-Poverty-Inequality Triangle in Asia and the Pacific” and National Science Foundation of China (NSFC) (Project 71133004). We thank Anna Guardia from CREAF for helping with land cover maps for Barcelona, Wenze Yue for providing data on land use and land cover of Shanghai in 2000 and 2010, and Gabriela Shirkey for editing the manuscript. We appreciate the constructive comments provided by guest editors of the special issue and anonymous reviewers to earlier versions of this paper. Any opinions, findings, and conclusions or recommendations expressed in this paper are those of the authors and do not necessarily reflect the views of NASA, ADB, or NSFC.

\section{References}

Ahern, J., 2013. Urban landscape sustainability and resilience: The promise and challenges of integrating ecology with urban planning and design. Landsc. Ecol. 28, 1203-1212.

Amin, A, Thrift N., 1994. Living in the global, in Amin A, Thrift N. (Eds.), Globalization, institutions and regional development in Europe, Oxford University Press, Oxford, 1-22.

Artmann, M., 2014. Assessment of soil sealing management responses, strategies, and targets toward ecologically sustainable urban land use management. Ambio 43, 530-541.

Barcelona City Council, 1996-2015. Barcelona city council statistical yearbook. Department of statistics, Barcelona city council, Barcelona, Spain. Retrieved October 10, 2016 at http://www.bcn.cat/estadistica

Barcelona City Council, 2013. Barcelona green infrastructure and biodiversity plan 2020. Barcelona: Barcelona city council. Retrieved October 21, 2016 at http://ajuntament.barcelona.cat/ecologiaurbana/sites/default/files/Barcelona\%20green\%20inf rastructure\%20and\%20biodiversity\%20plan\%202020.pdf

Basnou, C., Alvarez, E., Bagaria, G., Guardiola, M., Isern, R., Vicente, P., Pino, J., 2013. Spatial patterns of land use changes across a Mediterranean metropolitan landscape: Implications for biodiversity management. Environ. Manage. 52, 971-980.

Basnou, C., Vayreda, J., Pino, J., 2014. Serveis ecosistèmics de la infraestructura verda de l’Àrea 
metropolitana de Barcelona: primera diagnosi. Barcelona.

Beatley, T., 1991. A set of ethical principles to guide land use policy. Land Use Policy 8, 3-8

Beaverstock, J. V., Smith, R.G., Taylor, P.J., 1999. A roster of world cities. Cities 16, 445-458.

Bell, D., 1976. The Coming of the Post-Industrial Society. Educ. Forum 40, 574-579.

Boone, C.G., Buckley, G.L., Grove, J.M., Sister, C., 2009. Parks and people: An environmental justice inquiry in Baltimore, Maryland. Ann. Assoc. Am. Geogr. 99, 767-787.

Breuste, J., Artmann, M., Li, J., Xie, M., 2015. Special issue on green infrastructure for urban sustainability. J. Urban Plan. Dev. 141, A2015001.

Cassel, C., Hackl, P., Westlund, A.H., 1999. Robustness of partial least-squares method for estimating latent variable quality structures. J. Appl. Stat. 26, 435-446.

Catalan, B., Sauri, D., Serra, P., 2008. Urban sprawl in the Mediterranean: Patterns of growth and change in the Barcelona Metropolitan Region 1993 - 2000. Landsc. Urban Plan. 85, 174-184.

Chen, J., Zhao, B., Ren, W., Saunders, S.C., Ma, Z., Li, B., Luo, Y., Chen, J., 2008. Invasive Spartina and reduced sediments: Shanghai's dangerous silver bullet. J. Plant Ecol. 1, 79-84.

Chen, J., Zhu, L., Fan, P., Tian, L., Lafortezza, R., 2016. Do green spaces affect the spatiotemporal changes of PM2.5 in Nanjing? Ecol. Process. 5, 7.

Chen, W.Y., Hu, F.Z.Y., 2015. Producing nature for public: Land-based urbanization and provision of public green spaces in China. Appl. Geogr. 58, 32-40.

Chiesura, A., 2004. The role of urban parks for the sustainable city. Landsc. Urban Plan. 68, 129-138.

Cho, S., Choi, P.P., 2014. Introducing property tax in China as an alternative financing source. Land Use Policy 38, 580-586.

Curran, W., Hamilton, T., 2012. Just green enough: contesting environmental gentrification in Greenpoint, Brooklyn. Local Environ. 17, 1027-1042.

De Ridder, K., Adamec, V., Bañuelos, A., Bruse, M., Bürger, M., Damsgaard, O., Dufek, J., Hirsch, J., Lefebre, F., Pérez-Lacorzana, J.M., Thierry, A., Weber, C., 2004. An integrated methodology to assess the benefits of urban green space. Sci. Total Environ. 334-335, 489497.

European Commission, 2015. Towards an EU research and innovation policy agenda for naturebased solutions \& re-naturing cities: Final Report the Horizon 2020 Expert Group. Directorate-general for research and innovation-climate action, environment, resource efficiency and raw materials, Luxembourg.

Fan, P., Chen, J., John, R., 2016. Urbanization and environmental change during the economic transition on the Mongolian Plateau: Hohhot and Ulaanbaatar. Environ. Res. 144, 96-112.

Fan, P., Xu, L., Yue, W., Chen, J., 2017. (In Press) Accessibility of public urban green space in an urban periphery: The case of Shanghai. Landsc. Urban Plan. http://dx.doi.org/10.1016/j.landurbplan.2016.11.007

Fan, Y., Chen, J., Shirkey, G., John, R., Wu, S.R., Park, H., Shao, C., 2016. Applications of structural equation modeling (SEM) in ecological studies: An updated review. Ecol. Process. $5,19$.

Feige, E.L., 1994. The transition to a market economy in Russia: property rights, mass privatization and stabilization. In Alexander, G. S., Skapska, G. (Eds.), A Fourth way: privatization, property, and the emergence of new market economics. Routledge, New York, 
57-78.

Florida, R., 2005. Cities and the creative class. Routledge, New York.

Garcia Espuche, A., Rivero Matas, M., Montserrat Martí, J.M., Cortina Neus, I., 2008. Jardins, jardineria i botànica Barcelona 1700. Ajuntamente de Barcelona. Direccio de serveis editorials, Barcelona.

Gehl, J., 2010. Cities for people. Island Press, Washington DC.

Gong, C., Yu, S., Joesting, H., Chen, J., 2013. Determining socioeconomic drivers of urban forest fragmentation with historical remote sensing images. Landsc. Urban Plan. 117, 57-65.

Grace, J.B., 2006. Structural equation modeling and natural systems. Cambridge University Press, West Nyack, GB.

Hair, J.F., Hult, G.T.M., Ringle, C., Sarstedt, M., 2013. A primer on partial least squares structural equation modeling (PLS-SEM). Sage Publications, London.

Hair, J.F., Ringle, C.M., Sarstedt, M., 2011. PLS-SEM: Indeed a silver bullet. J. Mark. Theory Pract. 19, 139-152.

Hall, P., 1966. The world cities. Heinemann, London.

Hall, P., 2002. Global city-regions in the twenty-first century. Oxford University Press. Oxford.

Haughton, G., 1999. Environmental justice and the sustainable city. J. Plan. Educ. Res. 18, 233243.

Hsiao, H.H.M., Liu, H.J., 2004. Collective action toward a sustainable city: citizens' movements and environmental politics in Taipei, in: Wheeler, S.M., Beatley, T. (Eds.), The sustainable urban development reader. Routledge, London, 259-274.

Hymer, S., 1972. The multinational corporation and the law of uneven development. In Economics and World Order from the 1970s to the 1990s, in J Bhagwati (Ed.), CollierMacmillan, New York, 113-140.

Ianchovichina, E., 2007. Growth diagnostics for a resource-rich transition economy: The case of Mongolia (Vol. 4396). World Bank Publications, Washington DC.

International Monetary Fund (IMF), 2000a. Globalization: Threat or opportunity? Issues Brief. Retrieved Feburary 2, 2017 at http://www.imf.org/external/np/exr/ib/2000/041200.htm\#II.

International Monetary Fund (IMF), 2000b. Transition economies: An IMF perspective on progress and prospects. IMF, Washington DC.

Inostroza, L., 2014. Open spaces and urban ecosystem services. Cooling effect towards urban planning in South American cities. TEMA J. L. Use, Mobil. Environ. SI, 523-534.

Iojă, C.I., Grădinaru, S.R., Onose, D.A., Vânău, G.O., Tudor, A.C., 2014. The potential of school green areas to improve urban green connectivity and multifunctionality. Urban For. Urban Green. 13, 704-713.

Jacobs, A.B., 1993. Great streets. MIT Press, Cambridge, MA.

Kabisch, N., Frantzeskaki, N., Pauleit, S., Naumann, S., Davis, M., Artmann, M., Haase, D., Knapp, S., Korn, H., Stadler, J., Zaunberger, K., Bonn, A., 2016. Nature-based solutions to climate change mitigation and adaptation in urban areas: perspectives on indicators, knowledge gaps, barriers, and opportunities for action. Ecol. Soc. 21. 39.

Kubo, K., 2013. Myanmar's two decades of partial transition to a market economy: A negative legacy for the new government. Post-Communist Econ. 25, 357-370.

La Rosa, D., 2014. Accessibility to greenspaces: GIS based indicators for sustainable planning in a dense urban context. Ecol. Indic. 42, 122-134. 
LeGates, R.T., Stout, F., 2015. The city reader, Sixth. ed. Routledge, New York, NY.

Levitt, T., 1983. The globalization of markets. Harv. Bus. Rev. 61, 92-102.

Llausas, A., Roe, M., 2012. Green infrastructure planning: Cross-national analysis between the north east of England (UK) and Catalonia (Spain). Eur. Plan. Stud. 20, 641-663.

Maes, J., Jacobs, S., 2015. Nature-based solutions for Europe’s sustainable development. Conserv. Lett. doi: 10.1111/conl.12216.

Marshall, T., 2000. Urban planning and governance: Is there a Barcelona model? Int. Plan. Stud. 5, 299-319.

McGarigal, K., Cushman, S.A., Neel, M.C., Ene, E., 2002. FRAGSTATS: Spatial pattern analysis program for categorical maps. Computer software program produced by the authors at the University of Massachusetts, Amherst. www.umass.edu/landeco/research/fragstats/fragstats.html

McGranahan, G., Jacobi, P., Songsore, J., Surjadi, C., Kjellen, M., 2001. The citizens at risk: From urban sanitation to sustainable cities, Earthscan Risk in Society. Earthscan, London.

Metaxas, T., 2010. Cities competition, place marketing and economic development in South Europe: The Barcelona case as FDI destination. Theor. Empir. Res. Urban Manag. 5, 5-19.

Monclús, F.J., 2003. The Barcelona model: and an original formula? From "reconstruction" to strategic urban projects (1979-2004). Plan. Perspect. 18, 399-421.

Nature England, 2010. Nature nearby: Accessible natural greenspace guidance. Natural England, Peterborough.

Niemelä, J., 2014. Ecology of urban green spaces: The way forward in answering major research questions. Landsc. Urban Plan. 125, 298-303.

Parcerisas, L., Marull, J., Pino, J., Tello, E., Coll, F., Basnou, C., 2012. Land use changes, landscape ecology and their socioeconomic driving forces in the Spanish Mediterranean coast (El Maresme County, 1850-2005). Environ. Sci. Policy 23, 120-132.

Rabinovitch, J., Leitman, J., 2004. Urban planning in Curitiba, in: Wheeler, S.M., Beatley, T. (Eds.), The sustainable urban development reader. Routledge, London, 236-249.

Reed, H C., 1981. The Preeminence of International financial centers. Praeger, New York. Robertson, R., 1992. Globalization: Social theory and global culture (Vol. 16). Sage, London.

Rouse, J.W., Haas, R.H., Scheel, J.A., Deering, D.W., 1974. Monitoring vegetation systems in the Great Plains with ERTS, in: The 3rd Earth Resource Technology Satellite (ERTS) Symposium. 48-62.

Sassen, S., 1991. The global city. Princeton University Press, Princeton, NJ.

Sassen, S., 1999. Globalization and its discontents: Essays on the new mobility of people and money. New Press, New York.

Sassen, S., 2001. The global city: New York, London, Tokyo. Princeton University Press, Princeton, NJ.

Satterthwaite, D., 1997. Sustainable cities or cities that contribute to sustainable development? Urban Stud. 34, 1667-1691.

Shanghai Bureau of Statistics. 2000-2015. Shanghai statistical yearbook (various years). Shanghai: Shanghai Bureau of Statistics.

Stern, D.I., Common, M.S., Barbier, E.B., 1996. Economic growth and environmental degradation: the environmental Kuznets curve and sustainable development. World Dev. 24, 1151-1160. 
Tian, L., Chen, J., Yu, S.X., 2014. Coupled dynamics of urban landscape pattern and socioeconomic drivers in Shenzhen, China. Landsc. Ecol. 29, 715-727.

Touraine, A., 1971. The post-industrial society. Tomorrow's social history: Classes, conflicts and culture in the programmed society. Random House, New York.

Wolch, J.R., Byrne, J., Newell, J.P., 2014. Urban green space, public health, and environmental justice: The challenge of making cities “just green enough.” Landsc. Urban Plan. 125, 234244.

Xu, H., 2007. Extraction of urban built-up land features from Landsat imagery using a thematicoriented index combination technique. Photogramm. Eng. Remote Sensing 73, 1381-1391.

Yue, W., Liu, Y., Fan, P., Ye, X., Wu, C., 2012. Assessing spatial pattern of urban thermal environment in Shanghai, China. Stoch. Environ. Res. Risk Assess. 26, 899-911.

Yusuf, S., Wu, W., 2002, Pathways to a world city: Shanghai rising in an era of globalisation. Urban Stud. 39, 1213-1240.

Zhang, L., 2013. Acknowledgement from people is the main factor driving urban green space dynamics - reflection on Shanghai ecosystem planning. Shanghai Bureau of Green City Image. Retrieved September 1, 2016 at

http://lhsr.sh.gov.cn/sites/wuzhangai_lhsr/neirong.aspx?ctgid=3a222e8f-e1e5-4737-869741de8c789e31\&infid=fd3b1ff2-eb2b-426b-888e-659f11176c9e

Zhou, X.L., Wang, Y.C., 2011. Spatial-temporal dynamics of urban green space in response to rapid urbanization and greening policies. Landsc. Urban Plan. 100, 268-277. 


\section{Tables and Figures}

Table 1.The acquisition time and path/row of Landsat images used for classifying urban built-up land and calculating land surface temperate for Barcelona and Shanghai.

\begin{tabular}{|c|c|c|c|c|}
\hline & \multicolumn{2}{|c|}{ Barcelona(BCL) } & \multicolumn{2}{|c|}{ Shanghai(SHG) } \\
\hline & Date & Path/Row & Date & Path/Row \\
\hline \multicolumn{5}{|c|}{ Urban Built-up Area } \\
\hline 1980s & $1985 / 7 / 24$ & 198/31 & $1984 / 5 / 16$ & 118/38;118/39 \\
\hline 1990s & $1992 / 7 / 29$ & 198/31 & $1990 / 12 / 4$ & $118 / 38 ; 118 / 39$ \\
\hline $2000 \mathrm{~s}$ & 2002/6/21 & 198/31 & $2000 / 5 / 21$ & 118/38;118/39 \\
\hline $2010 \mathrm{~s}$ & $2011 / 6 / 21$ & 198/31 & $2011 / 5 / 20$ & 118/38;118/39 \\
\hline \multicolumn{5}{|c|}{ Land Surface Temperature } \\
\hline 1980s & $1985 / 7 / 24$ & 198/31 & 1984/5/16 & $180 / 38$ \\
\hline 1990s & $1992 / 7 / 29$ & 198/31 & $1994 / 5 / 5$ & $180 / 38$ \\
\hline $2000 \mathrm{~s}$ & $2002 / 6 / 21$ & 198/31 & $2000 / 5 / 21$ & $180 / 38$ \\
\hline 2010s & $2011 / 6 / 21$ & 198/31 & $2011 / 5 / 20$ & $180 / 38$ \\
\hline
\end{tabular}


Table 2. Landscape metrics of green spaces and water surface. GREEN indicates green coverage.

\begin{tabular}{|c|c|c|c|c|}
\hline \multirow[t]{2}{*}{ Barcelona (BCL) } & \multicolumn{2}{|c|}{1993} & \multicolumn{2}{|c|}{2010} \\
\hline & GREEN & Water Surface & GREEN & Water Surface \\
\hline PLAND & 45.74 & 0.42 & 46.07 & 0.56 \\
\hline AREA_MN & 19.38 & 2.61 & 17.82 & 1.97 \\
\hline FDI & 1.13 & 1.17 & 1.13 & 1.16 \\
\hline PD & 2.35 & 0.16 & 2.58 & 0.28 \\
\hline SHDI & \multicolumn{2}{|c|}{1.08} & \multicolumn{2}{|c|}{1.01} \\
\hline SHEI & \multicolumn{2}{|c|}{0.67} & \multicolumn{2}{|c|}{0.63} \\
\hline \multirow[t]{2}{*}{ Shanghai (SHG) } & \multicolumn{2}{|c|}{2000} & \multicolumn{2}{|c|}{2010} \\
\hline & GREEN & Water Surface & GREEN & Water Surface \\
\hline PLAND & 1.89 & 16.9 & 3.85 & 9.38 \\
\hline AREA_MN & 0.91 & 1.18 & 1.45 & 2.79 \\
\hline FDI & 1.06 & 1.07 & 1.06 & 1.07 \\
\hline PD & 1.66 & 11.45 & 2.07 & 14.3 \\
\hline SHDI & \multicolumn{2}{|c|}{1.05} & \multicolumn{2}{|c|}{1.07} \\
\hline SHEI & \multicolumn{2}{|c|}{0.76} & \multicolumn{2}{|c|}{0.77} \\
\hline
\end{tabular}

Note: SHDI (Shannon's diversity index) and SHEI (Shannon's evenness index) are landscapelevel metrics calculated based on four classes (built-up land, green land, farmland, and water surface). PLAND (proportion of the landscape occupied by the patch type), AREA_MN (mean area of all patches of a class in a hectare), FDI (fractal dimension index), and PD (patch density) are class-level metrics that were calculated for green land and water surface separately. 
Table 3. Land use and land cover conversion matrix $\left(\mathrm{km}^{2}\right)$ for Barcelona (1993-2009, top)and Shanghai (2000-2010, bottom). Note: The annual conversion rate for the corresponding periods was included in parentheses $\left(\mathrm{km}^{2} \mathrm{yr}^{-1}\right)$. GREEN indicates total green coverage.

\begin{tabular}{|c|c|c|c|c|c|c|c|c|c|}
\hline \multicolumn{2}{|c|}{ Barcelona (BCL) } & \multicolumn{8}{|c|}{1993} \\
\hline & & $\begin{array}{r}\text { Urban } \\
\text { Land }\end{array}$ & (\%) & GREEN & $(\%)$ & $\begin{array}{r}\text { Farm } \\
\text { land }\end{array}$ & $(\%)$ & $\begin{array}{r}\text { Water } \\
\text { Surface }\end{array}$ & $(\%)$ \\
\hline \multirow[t]{4}{*}{2009} & $\begin{array}{l}\text { Urban } \\
\text { Land }\end{array}$ & 186.4 & 76.8 & $\begin{array}{l}27.29 \\
(1.39)\end{array}$ & 11.3 & $\begin{array}{r}28.5 \\
(1.78)\end{array}$ & 11.8 & $\begin{array}{r}0.28 \\
(0.02)\end{array}$ & 0.1 \\
\hline & GREEN & $\begin{array}{r}10.1 \\
(0.63)\end{array}$ & 3.7 & $\begin{array}{r}233.78 \\
(14.6)\end{array}$ & 86.0 & 27.3 & 10.0 & $\begin{array}{r}0.76 \\
(0.05) \\
\end{array}$ & 0.3 \\
\hline & Farmland & $\begin{array}{r}2.85 \\
(0.18)\end{array}$ & 4.0 & 8.17 & 11.4 & $\begin{array}{l}60.15 \\
(3.76)\end{array}$ & 84.2 & $\begin{array}{r}0.26 \\
(0.02)\end{array}$ & 0.4 \\
\hline & $\begin{array}{l}\text { Water } \\
\text { Surface }\end{array}$ & $\begin{array}{r}0.10 \\
(0.006)\end{array}$ & 3.0 & $\begin{array}{r}0.81 \\
(0.05)\end{array}$ & 24.5 & $\begin{array}{r}1.19 \\
(0.07)\end{array}$ & 36.0 & 1.2 & 36.4 \\
\hline \multicolumn{2}{|c|}{ Shanghai (SHG) } & & & & 2000 & & & & \\
\hline \multirow[t]{4}{*}{2010} & $\begin{array}{l}\text { Urban } \\
\text { Land }\end{array}$ & $1,566.3$ & 54.2 & $\begin{array}{r}52.45 \\
(5.245)\end{array}$ & 1.8 & $\begin{array}{l}1,043.16 \\
(104.32)\end{array}$ & 36.0 & $\begin{array}{l}232.54 \\
(23.25)\end{array}$ & 8.0 \\
\hline & GREEN & $\begin{array}{l}42.84 \\
(4.28)\end{array}$ & 16.9 & 38.98 & 15.4 & $\begin{array}{r}142.00 \\
(14.20)\end{array}$ & 56.2 & $\begin{array}{r}29.02 \\
(2.90)\end{array}$ & 11.5 \\
\hline & Farmland & $\begin{array}{l}46.51 \\
(4.65)\end{array}$ & 1.7 & $\begin{array}{l}29.36 \\
(2.94)\end{array}$ & 1.1 & $2,382.07$ & 85.0 & $\begin{array}{l}342.88 \\
(34.29)\end{array}$ & 12.2 \\
\hline & $\begin{array}{l}\text { Water } \\
\text { Surface }\end{array}$ & $\begin{array}{l}29.51 \\
(2.95)\end{array}$ & 4.8 & $\begin{array}{r}3.33 \\
(0.33)\end{array}$ & 0.5 & $\begin{array}{l}74.81 \\
(7.48)\end{array}$ & 12.1 & 508.68 & 82.6 \\
\hline
\end{tabular}


Table 4. Major policy implementations of nature based solutions (NBS)and affected areas in Barcelona and Shanghai. GREENpc indicates total green space per capita.

\begin{tabular}{|c|c|c|}
\hline Period & $\begin{array}{r}\text { GREENpc } \\
\mathrm{m}^{2} \text { (year) }\end{array}$ & $\begin{array}{l}\text { Main economic and planning context; } \\
\text { NBS characters and major spatial outcomes }\end{array}$ \\
\hline \multicolumn{3}{|c|}{ Barcelona (BCL) } \\
\hline Before 1950 & & $\begin{array}{l}\text { Industrialization since the nineteenth century. Ildefons Cerdà designed } \\
\text { famous Eixample District in the 1850s; } \\
\text { At regional level, the spread of the Grape Phylloxera plague provoked } \\
\text { vineyards crash; } \\
\text { Parc de la Ciutadella was the only city park until 1929; Montjuïc Park } \\
\text { created in } 1929 \text { for the World Expo; } \\
\text { Spanish Civil War (1936-1939) led to poor economic development }\end{array}$ \\
\hline $1950-1980$ & $\begin{array}{l}18.0(1956) \\
13.2(1977)\end{array}$ & $\begin{array}{l}\text { The city and its metropolitan area expanded quickly with migrant } \\
\text { populations from poorer areas of Spain; Rapid urban expansion led to } \\
\text { decrease in urban green land }\end{array}$ \\
\hline 1981-1992 & & $\begin{array}{l}\text { Revival of the tertiary sector; Newly created green areas; Parc de } \\
\text { Collserola under special protection plan in } 1987\end{array}$ \\
\hline $1993-2012$ & $\begin{array}{r}11.4(1993) \\
6.2(1998) \\
6.6(2006) \\
6.8(2012)\end{array}$ & $\begin{array}{l}\text { Olympic Games in 1992, Barcelona experienced important urban } \\
\text { changes and touristic boom; Seafront/beach of the city restored; many } \\
\text { green areas created; the Air Quality Plan (2011-2015); Economic } \\
\text { crises in Europe in } 2008 \text { also struckSpain; Increased unemployment } \\
\text { rate in } 2010 \text { and } 20 \% \text { poverty rate in } 2011 \text { in the MAB; }\end{array}$ \\
\hline 2013-present & $7.0(2014)$ & $\begin{array}{l}\text { A recovery trend in economy in recent years. NBS basis: Green and } \\
\text { Biodiversity Plan (2012-2020); NBS strategies focused on greenery } \\
\text { and biodiversity are promoted at various levels (city and metropolitan } \\
\text { area); Restoration of Besòs and Llobregat Rivers; Actions battling air } \\
\text { pollution (i.e. "aday without cars") }\end{array}$ \\
\hline \multicolumn{3}{|r|}{ 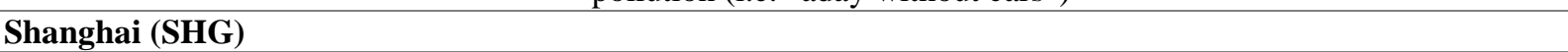 } \\
\hline Before 1949 & 0.1 (1949) & $\begin{array}{l}\text { No systematic planning of NBS; } 17 \text { parks built at concession areas for } \\
\text { foreigners and upper-class; no public green space for lower class } \\
\text { residents }\end{array}$ \\
\hline 1949-1978 & 0.5 (1978) & $\begin{array}{l}\text { Industrialization is a priority; urban green space grew at a low speed; } \\
\text { NBS focusing on inner city redevelopment and creating parks for } \\
\text { inner city districts, along the water way, and converting waterway into } \\
\text { a green corridor }\end{array}$ \\
\hline 1978-1998 & 3.0 (1998) & $\begin{array}{l}\text { Economic reform started; NBS focused on green belt development on } \\
\text { the outer ring road and to create a green network with points, lines, } \\
\text { and areas }\end{array}$ \\
\hline 1998-2005 & $8.8(2005)$ & $\begin{array}{l}\text { Shanghai put tertiary sector as the priority for its economic structure; } \\
\text { NBS changed from piecemeal "insert greenness in city" strategy to } \\
\text { "green space planning", proposed comprehensive networks of green } \\
\text { belt, wedge, corridor, park, and forest. }\end{array}$ \\
\hline 2005-2009 & $11.0(2005)$ & $\begin{array}{l}\text { Globalizing Shanghai; NBS focusing on a high-quality environment } \\
\text { to attract global investment and elite professionals, proposing spatial } \\
\text { patterns connecting green nucleus, belts, corridors, wedges, and } \\
\text { networks }\end{array}$ \\
\hline $\begin{array}{l}2009- \\
\text { present }\end{array}$ & 12.0 (2014) & $\begin{array}{l}\text { Shanghai as a regional center for global economics, finance, trade, } \\
\text { and shipping; NBS focusing on ecological city and urban } \\
\text { sustainability; Institutional streamlining of planning and land } \\
\text { management to make NBS more efficient }\end{array}$ \\
\hline
\end{tabular}




\section{Figure Captions}

Figure 1. The locations of Barcelona, Spain and Shanghai, China. The administrative boundary of Greater Barcelona ("Comarca")and Shanghai are drawn with the same scale.

Figure 2.Changes in Barcelona (BCL) and Shanghai (SHG): (a) population; (b) immigration and emigration; and (c) gross domestic production (GDP) and GDP per capita (GDPpc).

Figure 3. Spatial-temporal changeof urban built-up area (a) from the 1950s to 2010s in Barcelona and(b) from the 1980s to 2010s in Shanghai.

Figure 4. Total green space (GREEN) in Barcelona (1993 \& 2009) and Shanghai (2000 \& 2010). Note the scales are different for Barcelona and Shanghai for presentation purpose.

Figure 5. Changes of total urban greenspace (GREEN) and urban green space per capita (GREENpc) in Barcelona (BCL) and Shanghai (SHG).

Figure 6. Empirical and modeled relationships between (a) population and economic development and (b) urban green space per capita (GREENpc) and population in Barcelona and Shanghai.

Figure 7. Partial least squared structural equation modeling (PLS-SEM) of economic development, globalization, and GREENpc in Barcelona (1986-2014) and Shanghai (19782014). The latent variables are labeled in circles and the measured variables are in squares. The path coefficients, describing the relationship between variables, are located on the path. 
Figure 1. The locations of Barcelona, Spain and Shanghai, China. The administrative boundary of Greater Barcelona ("Comarca") and Shanghai are drawn with the same scale.

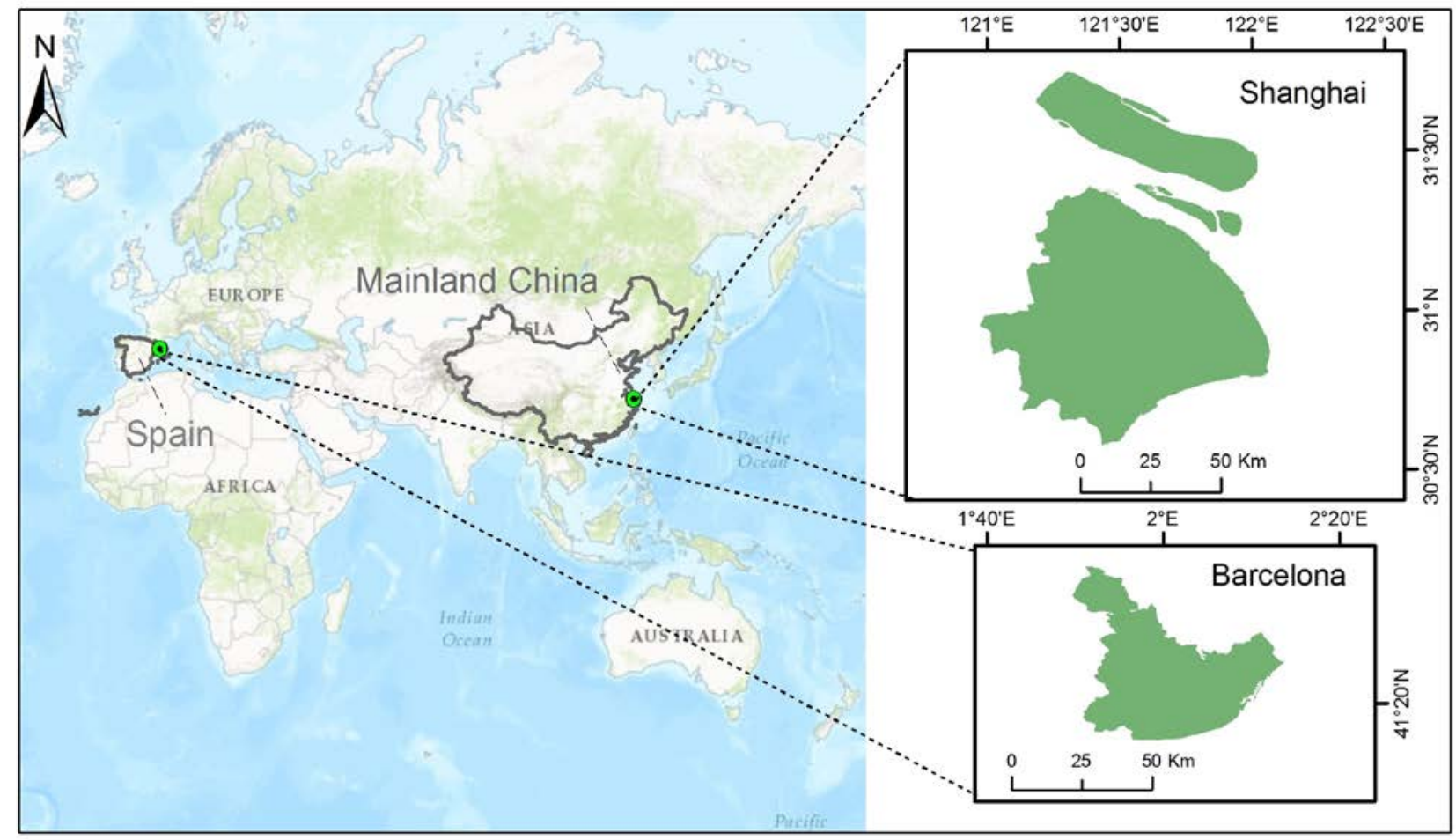


Figure 2. Changes in Barcelona (BCL) and Shanghai (SHG): (a) population; (b) immigration and emigration; and (c) gross domestic production (GDP) and GDP per capita (GDPpc).
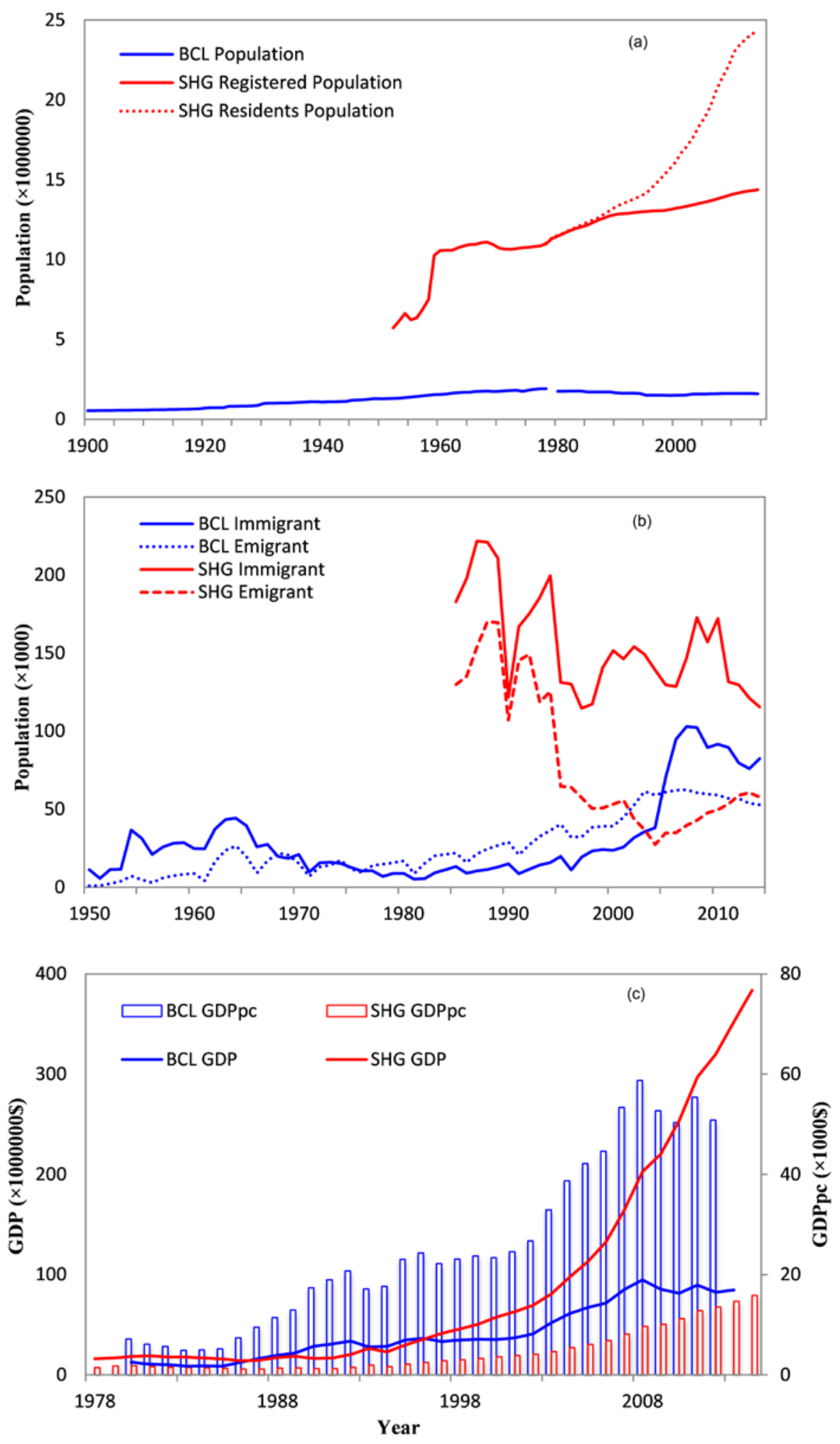
Figure 3. Spatial-temporal changeof urban built-up area (a) from the 1950s to 2010s in Barcelona and (b) from the 1980s to 2010s in Shanghai.
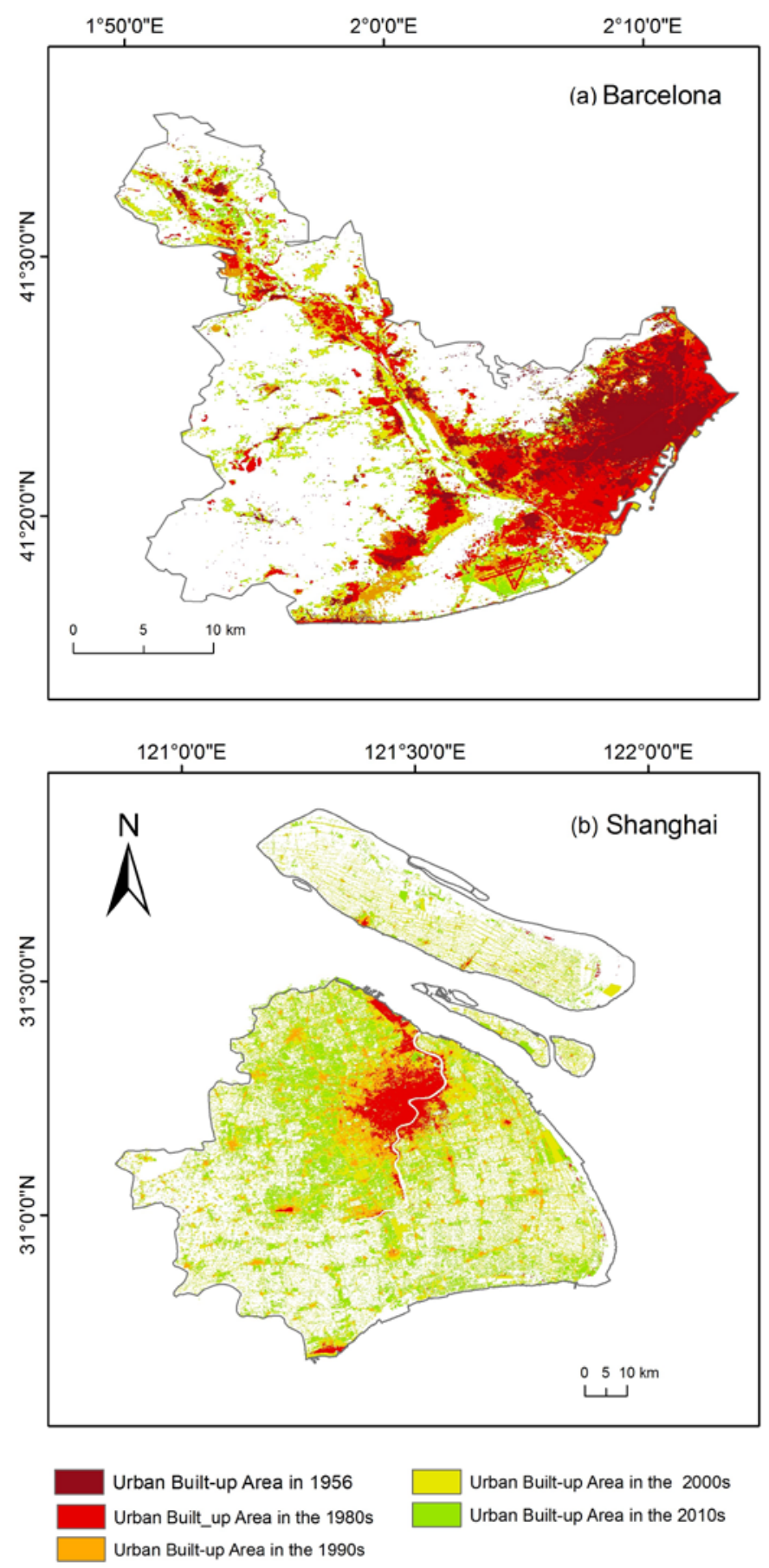
Figure 4. Total green space (GREEN) in Barcelona (1993 \& 2009) and Shanghai (2000 \& 2010). Note the scales are different for Barcelona and Shanghai for presentation purpose.
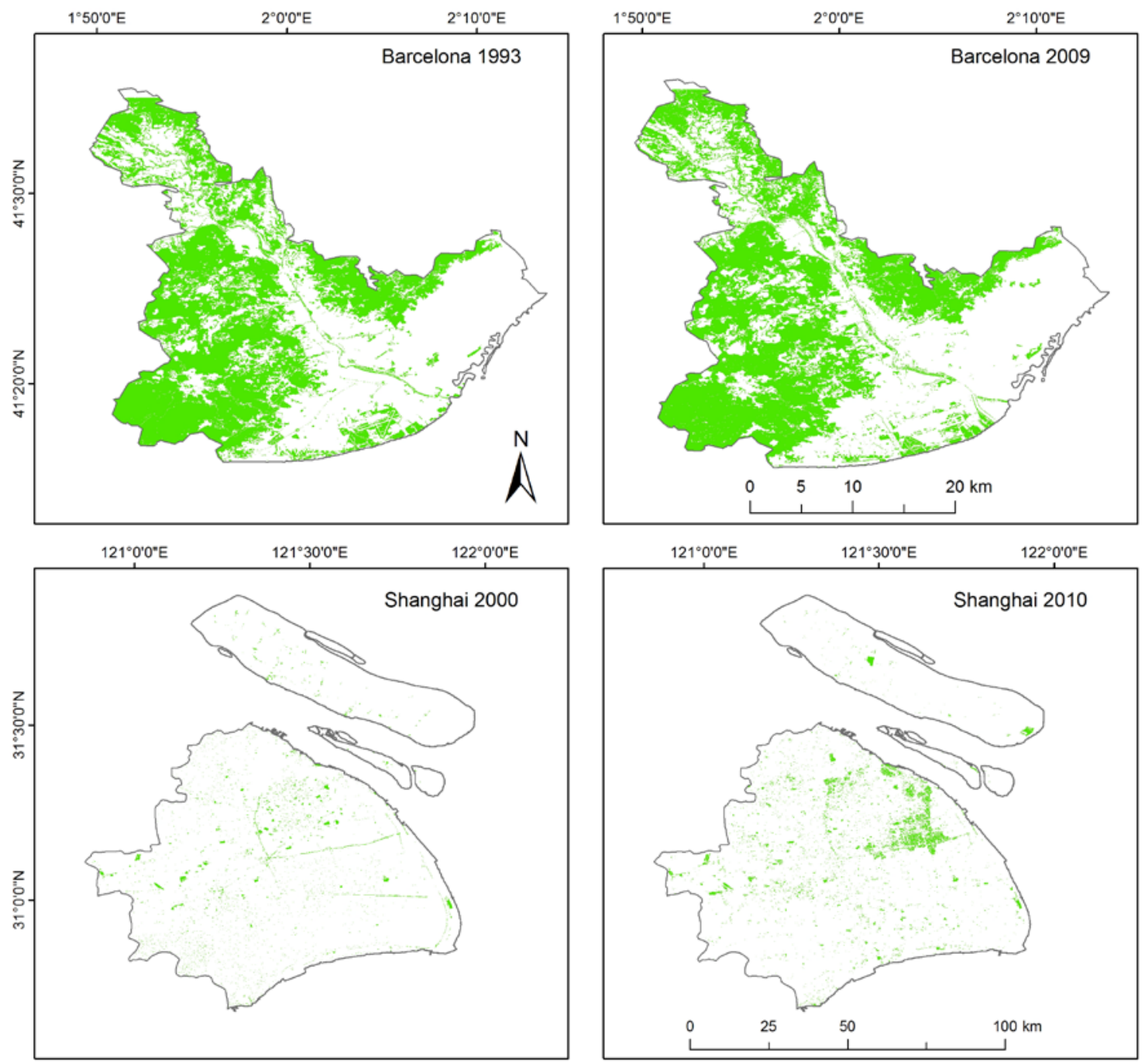
Figure 5. Changes of total urban green space (GREEN) and urban green space per capita (GREENpc) in Barcelona (BCL) and Shanghai (SHG).

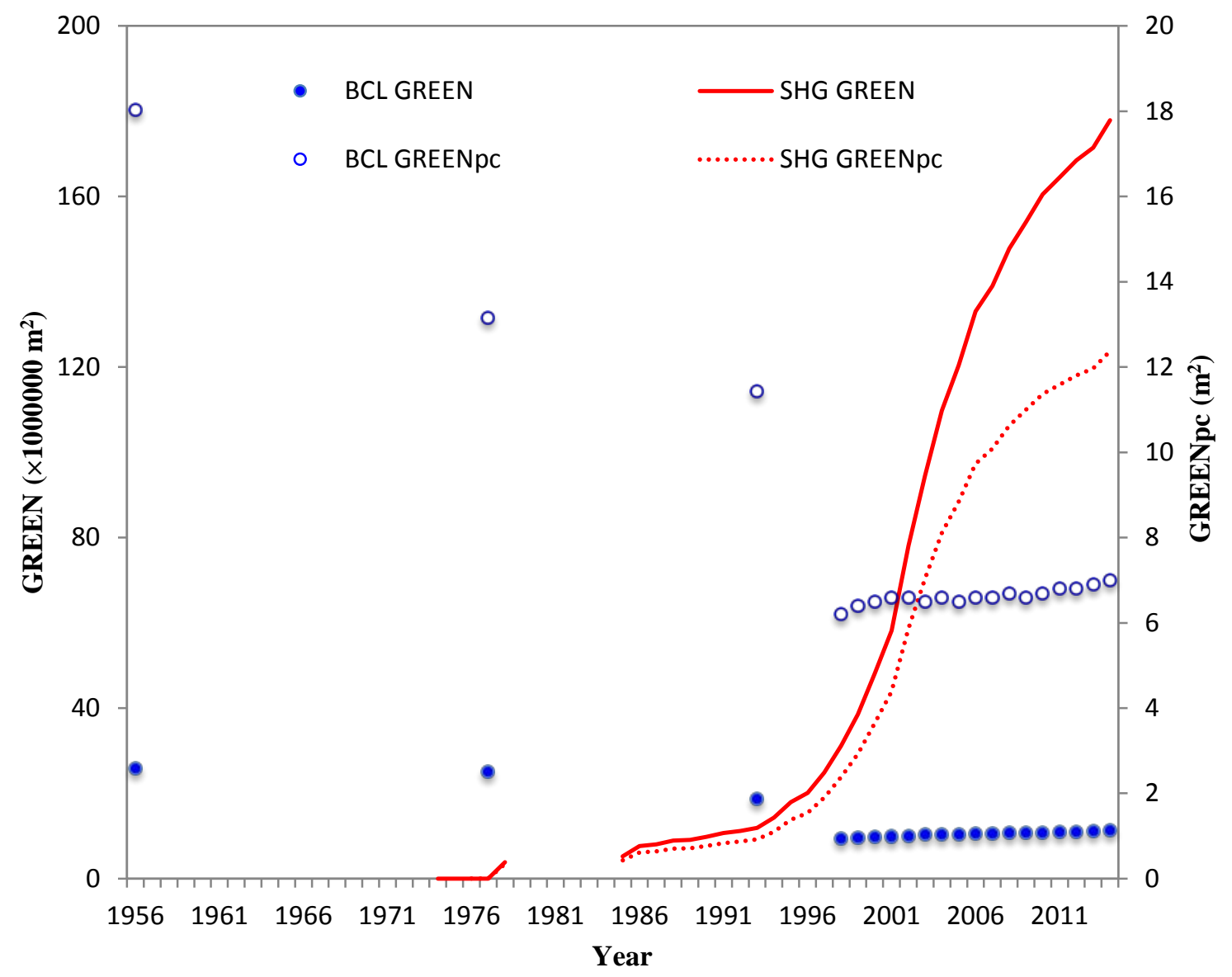


Figure 6. Empirical and modeled relationships between (a) population and economic development and (b) urban green space per capita (GREENpc) and population in Barcelona and Shanghai.
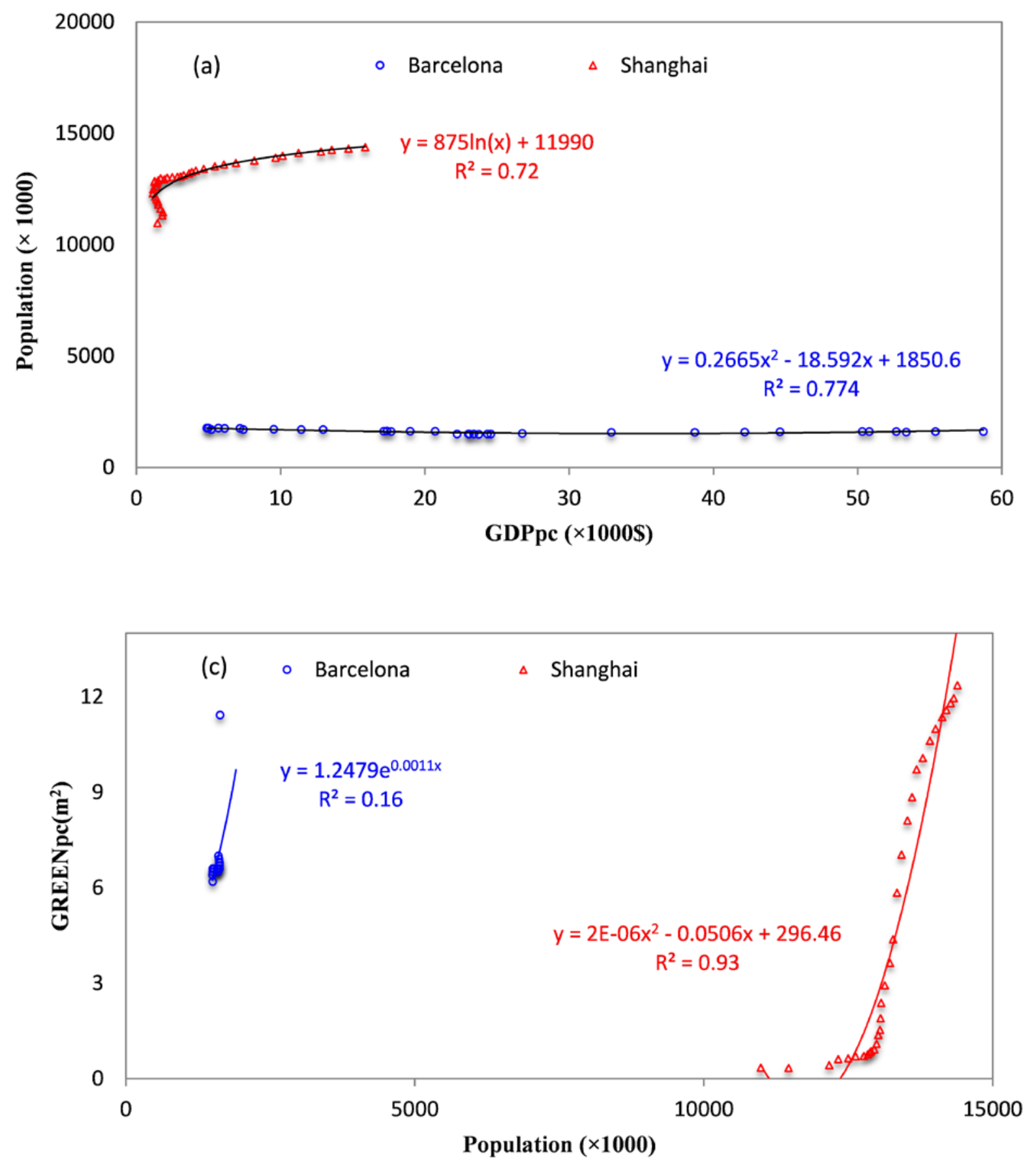
Figure 7. Partial least squared structural equation modeling (PLS-SEM) of economic development, globalization, and GREENpc in Barcelona (1986-2014) and Shanghai (19782014). The latent variables are labeled in circles and the measured variables are in squares. The path coefficients, describing the relationship between variables, are located on the path.
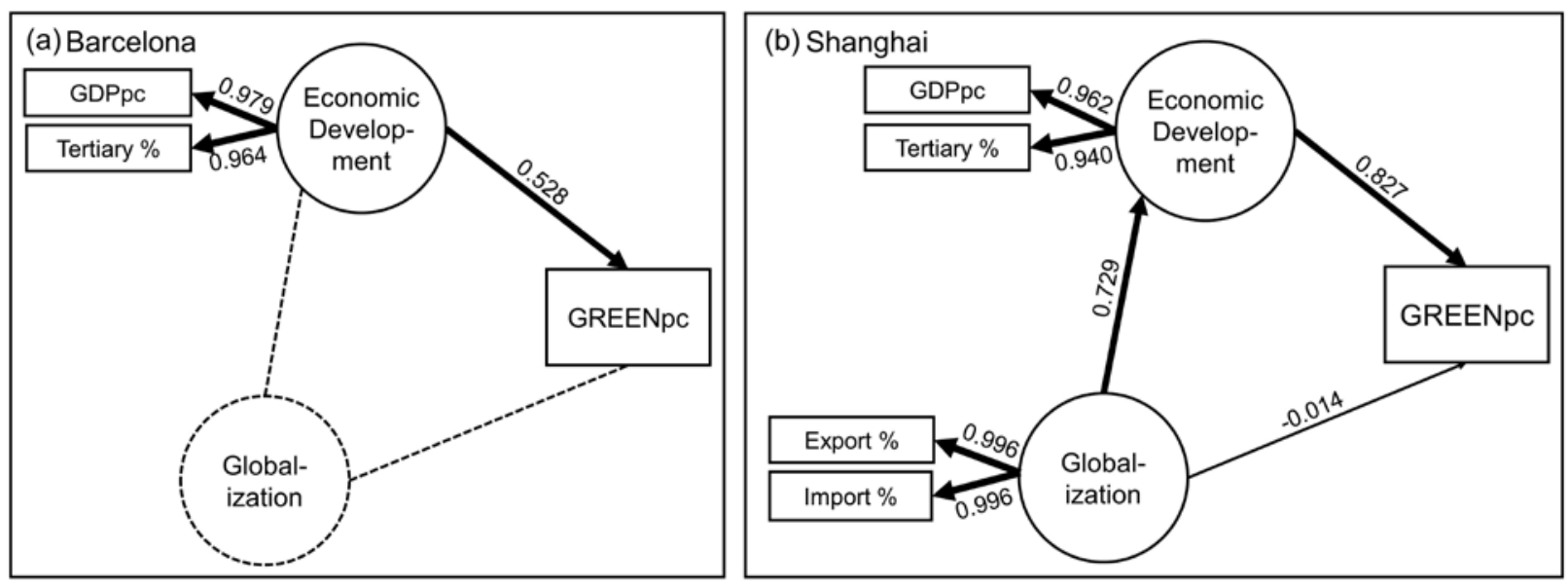